\title{
Deprem Sonrası Kentsel Yayılma Sürecine Dair Bir Değerlendirme: Kocaeli/ Gölcük Örneği
}

\author{
EImas UZUNER $^{1 *}$, Nilüfer AKINCITÜRK ${ }^{2}$
}

\section{Öz}

Insan yaşamının büyük bir kısmının geçtiği konutlar, barınma intiyacının ortaya çıkardığı mekânsal alanlardır. Kentsel doku üzerinde yoğun olarak bulunan konut alanları, kentlerin mücadele ettiği doğal afet, çarpık kentleşme, hızlı nüfus artışı, sosyo-ekonomik eşitsizlik gibi fiziksel, sosyal ve ekonomik sorunlarla karşılaşmaktadır. 1999 Marmara Depremi, merkez üssü Gölcük başta olmak üzere birçok kentte büyük hasarlara neden olmuştur. Gölcük'ün kent gelişimi sürecine bakıldığında; deprem öncesinde tersane ve diğer sanayi tesisleri nedeni ile kıyıda yerleşim daha yoğun iken, deprem sonrasında ise yeniden planlama sürecinde kıyı alanı zemin yapısının sağlam olmadığı tespit edilmiştir. Yeniden planlama sürecinde yeni konut alanları zemini sağlam doğal kaynakların bulunduğu güney kent çeperine kaydırılmıştır. Bu durum kentin güney çeperlerindeki tarım alanları ve ormanlık arazilerin tahribatına, tarihsel süreç içerisinde bu dağlık alanlarda kurulan tarihi ve kırsal dokunun zedelenmesine neden olmuştur. Kent çeperinde yaşanan bu yapılaşma sorunları çalışmanın önemli problemlerini oluşturmaktadır. Bu kapsamda Gölcük'ün mevcut kentleşme süreçleri ile konut planlama sisteminin uyumu, sürdürülebilirlik ve dirençlilik perspektifinden sorgulanacaktır. Alan çalışması için yerleşim ölçeğinde seçilen dokuların fiziksel, sosyal ve ekonomik sorunları; kentsel dirençlilik üzerinden bütüncül bir yaklaşımla ele alınmıştır. Kentsel dokuda ortaya çıkan sorunlara karşı dirençli ve sürdürülebilir kent planlaması, nitelikli konut ve yaşanabilir çevre üretimindeki farkındalığın sektördeki her alana yansıtılması için yol göstermesi hedeflenmektedir.

Anahtar Kelimeler: Deprem, yeniden planlama, kentsel yayılma, konutlar, Gölcük

\section{An Evaluation of Urban Sprawl Process Post-earthquake: Example of Kocaelil Gölcük}

\begin{abstract}
The houses where keep most of human life are spatial areas arising from the need for shelter. Housing areas densely located on the urban pattern are faced with problems as natural disaster, unplanned urbanization, rapid population growth, socio-economic inequality that cities struggle with. 1999 Marmara Earthquake caused substantial damages to houses in many cities, especially the center base of Gölcük. When the urban development process of Gölcük is examined, firstly the settlement on the coast was more intense due to the presence of the shipyard and other industrial facilities before the earthquake. After the earthquake, it was determined that the soil structure of the coastal areas was not strong during the re-planning process. For this reason, the grounds of new residential areas have been shifted to the southern city fringe, where hard ground and natural resources are found in re-planning process. Additionally, the new residential areas have been sprawled to the southern urban fringe which have hard ground and close to natural resources. This situation has caused the destruction of agricultural and forest areas in the southern fringe of the city, the destruction of historical and rural pattern established in these mountainous areas in the historical process. This construction problems in the city are important problems of the study. Harmonization of
\end{abstract}

\footnotetext{
${ }^{1}$ Bursa Uludağ Üniversitesi, Mimarlık Anabilim Dalı, Bursa, Türkiye

2 Bursa Uludağ Üniversitesi, Mimarlık Fakültesi, Mimarlık Bölümü, Bursa, Türkiye

*ilgili yazar / Corresponding author: elmasuzuner@yahoo.com
} 
the current urbanization process of Gölcük with the system of housing planning will be questioned on perspective of sustainability and resilience in this scope. Physical, social and economic problems of patterns where was chosen in the settlement scale for area of study has been discussed with an integrated view on urban resilience. Resilience and sustainable urban planning, awareness in producing qualified housing and livable environment are aimed to be the guidance in order that being reflected to every field in the sector against the problems of urban pattern.

Keywords: Earthquake, re-planning, rural sprawl, housing, Gölcük

\section{GíRiş}

Kentlerin gelişiminde doğa olayları, tarih boyunca mekânsal alanların oluşum sürecinde önemli bir etkiye sahip olmuştur. Kentlerde en çok yıkıma ve hasara yol açan doğa olayı ise depremlerdir. Nüfusun artmasıyla ortaya çıkan hızlı ve çarpık kentleşme, mevcut yapıların kalitesizliği, sosyo-ekonomik eşitsizlikten doğan yapılaşma sorunları, kullanıcıların deprem bilinci gibi sorunlar, kentin depreme karşı dayanıklılığını azaltmaktadır. Depreme duyarlı bölgelerde kaliteli konut üretimi için ilk parametre, kullanıcı ve ilgili aktörlerin katılımıyla zeminin sağlam olduğu alanlarda yaşam çevrelerini oluşturmaktır. Bu fiziksel çevreler, dokuinsan-yapı ilişkisi bağlamında farklı mekânsal sistemler halinde gelişerek günümüze kadar çeşitlilik göstermiştir. Bunun en belirgin hali konutlarda görülmektedir. Konut alanlarının doğru planlanması kentin depreme karşı daha dayanıklı olmasını, kısacası kentin dirençliliğinin artmasını sağlayacaktır. 'Dirençlilik' kavramı günümüzde disiplinler ve disiplinler arası çalışmalarla birlikte yorumlanmaya devam etmektedir.

Deprem sonrasında bozulan fiziksel çevrenin yeniden planlamasının, kentlerin hasar düzeyine ve konutların bulunduğu zemin özellikleri gibi faktörlere bağlı olarak yapılması gerekir. Bu planlama; depremde zarar gören yerleşimin çevre yerleşimlere dağıtılması, mevcut yerleşimdeki onarımların tamamlanıp aynı bölgede yeni yapılaşmanın sağlanması ya da depreme maruz kalan yerleşimin bölgeye yakın bir alanda yeni yapılaşma alanlarının oluşturulması şeklindedir (Coşkun, 2005). Yeni yerleşimlerin yer seçiminde mevcut yapılaşma alanı çevresinin tercih edilmesiyle deprem öncesi var olan kentsel doku genişleyerek kent çeperlerine doğru bir yayılma gösterir. Deprem sonrası izlenen bu planlamalarda yapılan eksik veya hatalar yerleşimlerin kırılganlığının artmasına, olası deprem anında mevcut hasarların yeniden tekrar etmesine yol açabilir.

\section{1. Çalışmanın Amaç, Kapsam ve Yöntemi}

Türkiye'de tarih boyunca birçok yıkıcı deprem meydana gelmiştir. Türkiye yüzölçümünün \% 96'sı, nüfusunun \% 99 'unun deprem riski altında olması, beşeri ve ekonomik faaliyetler açısından depremin önemini artırmaktadır. Özellikle 17 Ağustos 1999 İzmit ve 12 Kasım 1999 Düzce depremlerinin, nüfusun, yerleşim merkezlerinin ve sanayinin yoğun olduğu alanlarda meydana gelmiş olması çok sayıda can ve mal kayıplarının görülmesine neden olmuştur (Türkoğlu, 2001). Deprem etkisi, Gölcük'ün konut gelişiminde dönüm noktası olmuş; yapılan hatalar deprem sonrası yeniden planlama sorununu, nitelikli konut üretim sürecinin tekrar sorgulanmasını ve bu süreçlerde gerekli önlemlerin daha dikkatli alınması gerekliliğini ortaya koymuştur. Gölcük'ün kent gelişimi sürecine bakıldığında; deprem öncesinde tersane ve diğer sanayi tesisleri nedeni ile kıyıda yerleşim daha yoğun iken, deprem sonrasında ise yeniden planlama sürecinde kıyı alanı zemin yapısının sağlam olmadığı tespit edilmiştir. Yeniden planlama sürecinde yeni konut alanları zemini sağlam doğal kaynakların bulunduğu güney kent çeperine kaydırılmıştır. Bu planlama biçiminin şekillenmesi ile ilgili olarak çalışmanın amacı; depremle birlikte dönüşen ve yeniden planlanan güney kent çeperlerindeki konut alanlarının deprem öncesi süreci de dahil edilerek, deprem sonrası yeniden planlamada kentsel yayılım gösteren kent çeperi boyunca konutlardaki yapılaşma sorunlarını fiziksel ve sosyo-ekonomik açıdan analiz etmek ve 
değerlendirmeye sunmaktır. Bu kapsamda; depremde en çok yıkımın yaşandığı Kocaeli ili Gölcük ilçesi kentsel doku bazında incelenmiş, yerleşim ölçeğinde ise kentin güney çeperlerindeki kent-kır dokusu arasında kalan yerleşimlerin mevcut konut dokuları alan çalışması kapsamında ele alınmıştır. Araştırmanın yönteminde ise; tarihsel süreç içerisinde konut dokusundaki değişim, demografik yapı, fiziksel yapılaşmanın gelişimi, kullanıcıların bölgedeki sosyal yaşam döngüsü ve konutların ekonomik değerindeki değişim; konu ile ilgili literatür çalışması, yerinde gözlem ve toplu görüşmelerle tespit edilmeye çalışılmıştır.

\section{DIRENÇLILIIK ve AFET KAVRAMLARININ KENTSEL DOKU ÜZERINDEN OKUNMASI}

Dirençlilik kavramı, 1973'te ekoloji alanında yapılan öncü çalışmalarda kullanılıyorken, 1990'lardan sonra afet risk azaltma çalışmaları gibi birçok farklı disiplinler içinde kullanılmaya başlanmıştır. Bir sistemin dirençliliği yalnızca olay öncesi duruma dönmek, değişim meydana gelmeksizin durumu korumakla sınırlı değildir; aksine, bu kavram tüm sistemin yeniden yapılanması, sürdürülmesi ve gelişimini gözetir (Orhan, 2016).

Afet kavramı ise, insanları ve bulundukları çevreyi olumsuz yönde etkileyen fiziksel, sosyal, ekonomik zararlara yol açan, insanların günlük yaşantısını sekteye uğratan insan kaynaklı etkinliklerdir. Bu etkinlikler insan faktörlü olduğu için doğa olayları afete dönüşebilmektedir. Afet sonrası kayıpların en şiddetli yaşandığı yer kentsel yerleşim alanları ve yapılaşma alanlarıdır. Yaşadığımız çevre ve kentlerimizde etkili olan doğal afetler, kentler üzerinde olumsuz sonuçlara yol açmakta ve kentsel direnç kavramını ortaya çıkarmaktadır. Birleşmiş Milletler'in 2009 tarihli tanımında afetlere karşı kentsel direnç: "Her türlü tehlike/tehdit karşısında, etkilenme olasılığına sahip yerleşmelerin, toplumların ve tüm sistemlerin; kendilerini koruma, sistemin işleyişini güvence altına alma, kısa sürede yeniden yapılanma ve değişime uyum sağlama için gerekli kaynaklara sahip olması ve bu kaynakları etkin kullanım becerisi” şeklinde açıklanmıştır (Türkoğlu, 2014). Bu doğrultuda kentsel dirençlilik, yapısal çevre ve mekânsal alanların hiç hasar almamasından ziyade yerleşimlerin aldıkları bu hasarlar karşısında esneyebilme potansiyeli ve en kısa sürede kendini yenileyebilme kapasitesidir. Kentlerin afetlere karşı dirençli olabilmesi, afet öncesinde kentin fiziksel çevresi ve mekânsal kurgusu dahilindeki kararların alınmasına yönelik planlama anlayışı ile mümkündür. Planlama aşamasında deprem risklerinin belirlenmesi ve gerekli önlemlerin bu aşamada bütüncül bir biçimde ele alınması, kentin ve toplumun önemli fonksiyonlarını devam ettirebilecek şekilde adapte olabilme kapasitesini geliştirir.

\section{DEPREM SONRASI YENIDEN PLANLAMA AŞAMASINDA KENTSEL YAYILMA}

Kentler, deprem sonrası fiziksel çevrenin bozulmasıyla toparlanma sürecine girer. Depremin hemen ardından açığa çıkan konut intiyacı Türkiye'de ilk olarak acil yardım barınaklarıyla sağlanır. Bu süreçte fiziksel çevre üzerinde enkazların toplanması, ağır hasarlı yapıların yıkılması, az ve orta hasarlı yapılarda ise onarım- güçlendirme yapılması gerekir. Acil yardım barınaklarının konfor koşullarının yetersizliğinden dolayı afetzedeler sürekli yaşayacakları konutların yapım süreci tamamlanana kadar geçici barınma birimlerine yerleştirilir ve bir süre daha buralarda barınmaları sağlanır. Yapılı çevre tüm bu süreçten sonra rehabilite edilir ve yeni yerleşim alanlarının yer seçimi yapılır. 'Yeniden planlama aşaması' olarak adlandırılan bu süreçte mevcut yerleşimin zemin yapısı ve hasar durumuna bağlı olarak yeni yapılacak konutların yer seçimi kararlaştırılır.

Mevcut yerleşim alanının zemin yapısının sağlam olmamasından ya da enkaz kaldırma sürecinin güçlüğünden dolayı yeni oluşturulacak yerleşimler var olan çevre yerleşimlere dağıtılabilir. Bu durumlarda bu yerleşmelerin yeniden planlanması, düzensiz yapılaşmanın engellenmesi gerekir. Ayrıca nüfus artışı ile doğacak olan konut intiyacı ve iş olanakları uygun organizasyon ile birlikte planlanmalıdır. 
Hasar gören mevcut yerleşimin içinde de yeniden yapılaşma sağlanabilir. Bu durumda o yerleşim üzerinde yenileme çalışmaları yapılır. Yıkılan yapıların enkazı toparlanır, hasarlı yapıların ise onarım ve güçlendirme çalışmaları tamamlanır. Tüm bu çalışmaların ardından yasal düzenlemelerle desteklenen yeni planlama biçimlerine uygun yapı üretim sürecine başlanır.

Deprem öncesi yerleşimin uygun olmadığı alanlarda yapılaşma gerçekleşmişse; deprem sonrası ciddi hasarlar ortaya çıkar ve yeni yapılacak yapılar zemin etüdleri doğrultusunda zeminin daha sağlam olduğu arazilere kaydırılır. Bu alanlar çoğunlukla yerleşime kapalı tarım ya da ormanlık araziler olduğu için ilk aşama olarak bu arazilerin imara açılıp, yapı üretimi için gerekli düzenlemelerin yapılması gerekir. Yeni yerleşim alanlarında yapılaşma arttıkça kent dokusu, kentin çeperlerine doğru yayılma gösterir. Bazı bölgelerde bu planlama sürecinin sonunda çıkan birtakım sorunlar açığa çıkar. Araştırmanın bu sürece yönelik genel değerlendirmesi, 4.başlık altında ele alınan alan çalışmasıyla birlikte irdelenecektir.

\section{KOCAELI// GÖLCÜK'TE DEPREM SONRASI KENTSEL YAYILMA SÜRECINDE YAŞANAN SORUNLAR}

Kocaeli iline bağlı Gölcük ilçesi; kuzeyinde Marmara Denizi, güneyinde Samanlı Dağları ile çevrili doğal bir liman işlevi gören kıyı yerleşimidir. Bölgede bulunan tersane ve Gölcük Donanma Komutanlığı bölgenin stratejik ve politik konumunu; İstanbul, Bursa ve İzmit gibi önemli ticari merkezlerine yakınlığı ise bölgenin sahip olduğu coğrafi konumunun önemini açık bir şekilde göstermektedir (Şekil 1). İlçenin Kuzey Anadolu Fay Hattı üzerinde bulunması da deprem riskine yönelik kent üzerinde bütüncül bir yaklaşımla planlama yapılması gerekliliğini vurgulamaktadır.

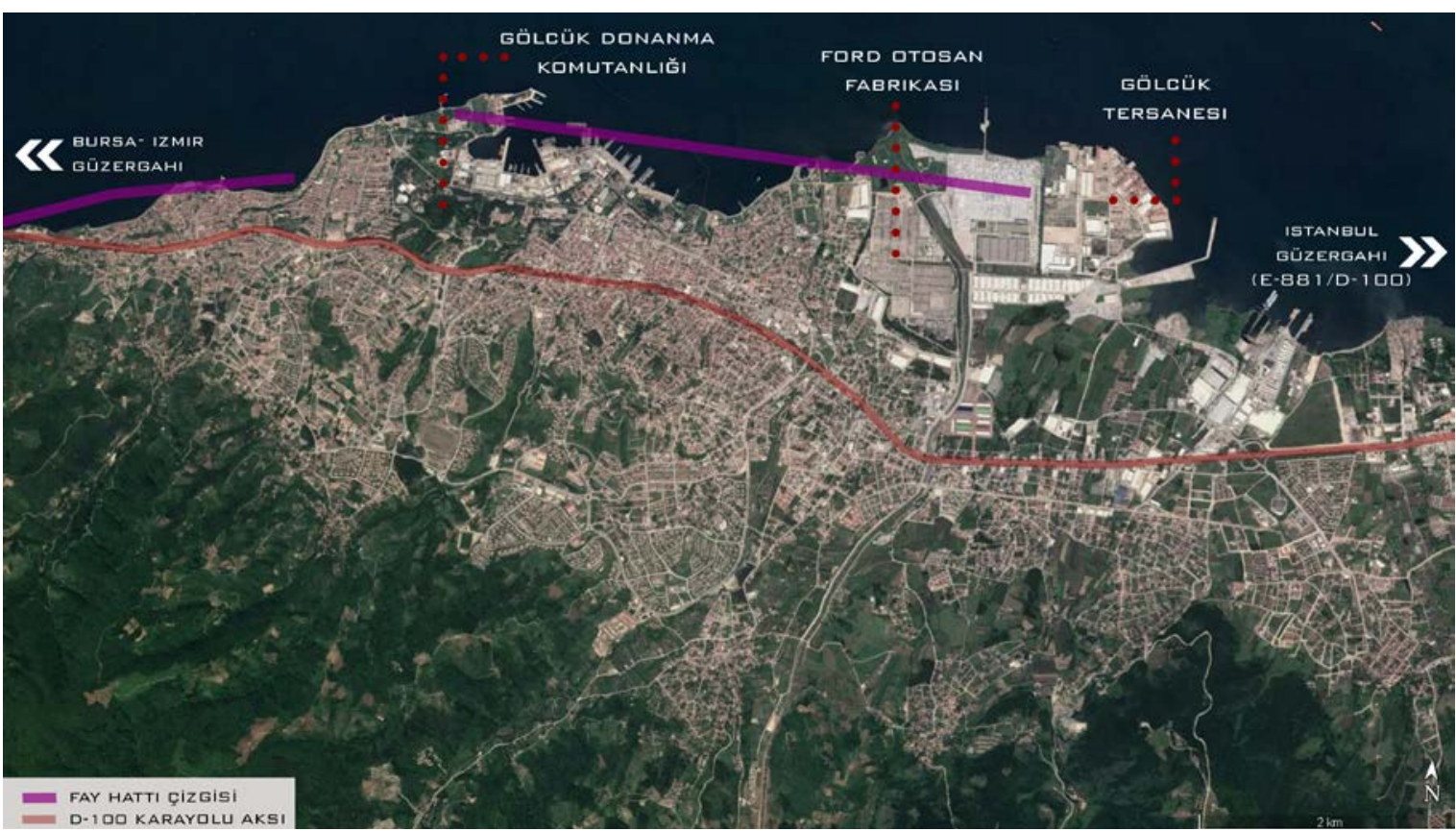

Şekil 1. Gölcük'ün kentsel dokusu ve stratejik konumunu gösteren 2018 yılı hava fotoğrafı

1999 Marmara Depremi, Gölcük'ün konut gelişiminde dönüm noktası olmuştur. İlçe kıyılarında sanayileşmenin artması nedeniyle kent dokusunun aşırı bir hızla gelişmesi, nüfusun artmasıyla birlikte deprem riski yüksek olan alanların da imara açılmasına neden olmuştur. Deprem öncesi sanayi ve askeri tesislerinin Gölcük'ün kıyı bölgesinde 
konumlanması ve manzara faktörü kullanıcıların konut seçiminde daha öncelikli iken; deprem sonrası yaşanan yıkım ve can kayıplarının yarattığı korku, bölgede yaşayan halkın zemini daha sağlam olan yeşil alan ve doğal kaynakların bulunduğu güney kent çeperlerine doğru kaymasına yol açmıştır. Bölgede deprem sonrasında gerçekleşen planlama sürecini ele almadan önce deprem öncesinde Gölcük'ün tarihsel süreç içerisinde konut gelişimini ele almak gerekir. Çalışmanın bu bölümünde alana ilişkin bilgi ve analizlerin iki başlık altında açıklanması daha doğru ve yerinde olacaktır.

\subsection{Deprem Öncesi Gölcük’te Kentleşme Süreci ve Konut Gelişimi}

Gölcük ve çevresinin tarihi, Bizans ve Roma dönemine kadar dayanmaktadır. Kıyısı bataklıklarla çevrili olan bölgede, Osmanlı dönemine ait önemli bir yerleşim olmadığı bilinmektedir. 1878 Harbi'nden sonra ise çoğunlukla Artvin yöresinden gelenler, ormanlık kesimlerde bulunan köylere yerleşmişlerdir (URL-1). Sanayinin henüz girmediği bölgede, halkın bulundukları konum itibariyle temel geçim kaynakları tarım odaklı olmuştur.

Bölgede kentsel gelişimin ilk adımı, 1925 yılında Yavuz Zırhlısı'nı tamir etmek amacıyla kurulan askeri tersane ile başlamıştır. Tersanenin varlığıyla birlikte 1933 yılında Donanma Ana Üssü bu bölgede kurulmuştur. Bu yapılara ek olarak fabrika, atölye, tesisler ve işçi evleri de inşa edilmesiyle bölgeye dışarıdan gelen göçler artmıştır. 1940-1997 yılları arasında da ilçenin toplam nüfus miktarı sürekli artış göstermiştir. Bu dönemde manzara, yer şekilleri, kırsal kesimde tarım ve hayvancılığa dayalı ekonomideki düşüş, zamanla ekonominin sanayiye kayması, sosyal imkanların elverişliliği gibi sebeplerden dolayı ilçe dışından bölgeye olan göçlerin gittikçe artmasına ve kent içinde güneyden kuzeye doğru nüfusun yer değiştirmesine neden olmuştur. Kent dokusunda oluşan bu dağılım, bölgenin kıyıda daha yoğun bir yerleşim düzeninin gelişmesine zemin hazırlamıştır (Şekil 2).

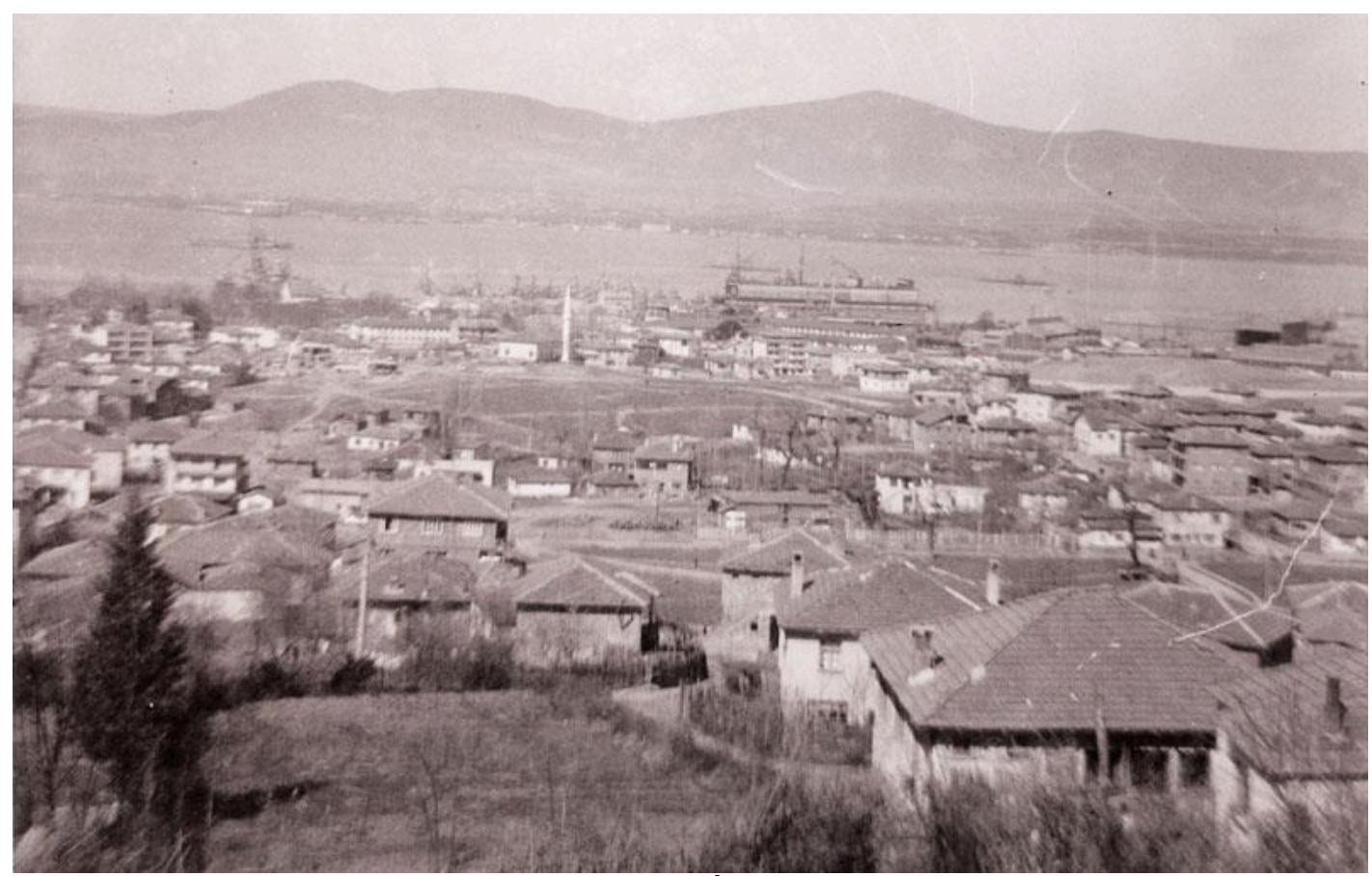

Şekil 2. 1950 Gölcük Sırtlarından İzmit Körfezi’ne Bakış (Ulugün Arşivi)

\subsection{Deprem Sonrası Gölcük'te Yeniden Planlama ve Kentsel Yayılma Süreci}

Gölcük, bulunduğu konum itibariyle tarih boyunca birçok depremle karşılaşmıştır. 17 Ağustos 1999 yılında gerçekleşen Marmara Depremi, merkez üssünün Gölcük olması nedeniyle depremde en fazla hasar gören yerleşimlerin başında gelmektedir. Bölgede 
depremin ciddi hasarlar ortaya çıkarmasının nedenleri ülke genelinde de benzer sebepler olan; hatalı yer seçim kararları, planlama ve denetlemedeki yanlışlar, malzeme ve işçilik kalitesinin düşük olması ve tüm bu kararları yönlendiren yasa-yönetmeliklerdeki eksikliklerdir.

Deprem sonrası Gölcük'te birçok yıkım yaşanmış ve yapılan hasar tespit çalışmaları sonucunda; bölgede geleneksel sistemle inşa edilmiş ahşap karkas, yığma ve kagir yapılardaki hasarın, betonarme sistemiyle inşa edilen yapılara oranla daha düşük olduğu ortaya çıkmıştır. Bu sonucun nedenlerinden en önemlileri ilk bakışta o dönemde betonarme yapıların sayısının daha fazla olduğu olarak görülse de betonarme konutlarda yapılan yerleşim hataları, taşıyıcı sistem hataları, malzeme-iş̧̧ilik ve denetim hataları olmuştur. Hasar durumu bölge bazında tekrar incelendiğinde; Değirmendere, Halıdere, Ulaşlı, İhsaniye gibi Gölcük'ün kıyı kesimlerinde bulunan yerleşimlerin deprem öncesinde yerleşime açık alanlar olması sebebiyle depremden daha fazla etkilendiği görülmüştür. Bu durum zemin özellikleri dikkate alınmadan yapılan yer seçim hatalarını göz önüne serse de, Gölcük'ün tarihsel süreç boyunca ilk yerleşim dokularının güney kesimlerinde yoğun olmasının nedenini doğrular nitelikte olmuştur.

Depremle birlikte fiziksel dokusu ciddi anlamda bozulan Gölcük'te, depremin hemen sonrasında acil yardım aşamasında ortaya çıkan konut intiyacı ile bölgenin boş, muhtelif alanlarına acil yardım barınakları olan çadırlar kurulmuştur. Çadırlar, kısa süreli barınma ihtiyacını karşılayabildiği için çadırların yerine geçici barınma birimleri olan prefabrik veya konteyner tipi konut yerleşimleri oluşturulmuştur. $O$ dönemde yerleşimin daha az ve zeminin daha sağlam olduğu güney çeperlerde bulunan Hisareyn'e Gölcük Kaymakamlığı verilerine göre yaklaşık 1.500, Örcün'e ise 1.600 kişi yerleştirilmiş olup, bu konutlar kalıcı konutların inşa süreci tamamlanana kadar 2 sene varlığını sürdürmeye devam etmiştir. Geçici konutların yer seçimi kararları ve yapılan jeolojik etüdler sonucunda, yeni yerleşim alanlarının konumlanacağı yer konusunda ön fikir oluşturulmuştur (Şekil 3).

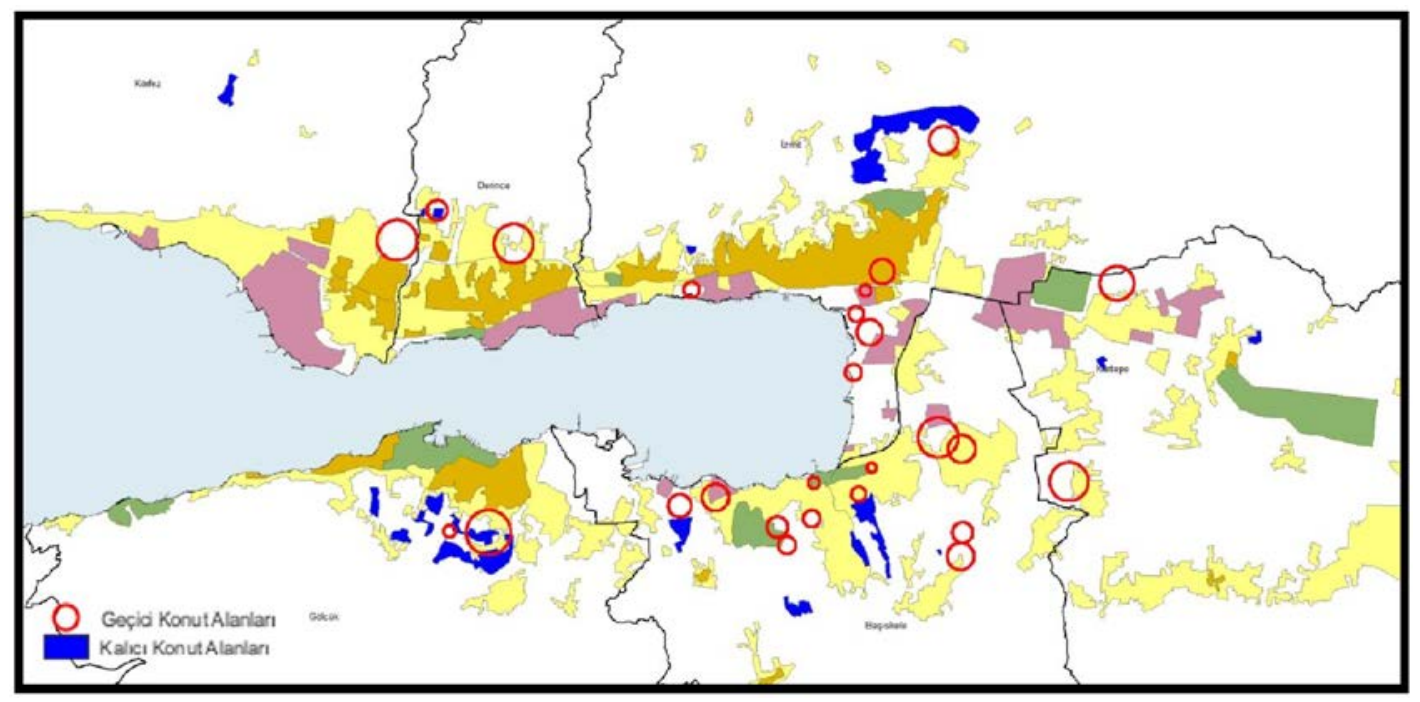

Şekil 3. 1999 Depremi sonrası geçici ve kalıcı konutların yer seçimi (KBB, 2018)

İlçenin güneyinde yer alan Şirinköy, Saraylı ve Örcün yerleşimlerinin yakın çevresine yaklaşık 4810 adet kalıcı konut inşa edilmiştir (Şekil 4). Deprem sonrasında bu konutlarda yaşayan kullanıcılarla görüşülerek akademik düzeyde kullanıcı memnuniyeti araştırması yapılmış ve görüşmeler sonucunda kalıcı konutların günümüzde değişen aile yapısına bağlı olarak yetersiz kaldığı, depreme dayanıklı olsa bile konut içinde yapılan ince işçilik ve malzeme seçimlerinin düşük kaliteli olduğu, merkeze uzaklığı nedeniyle erişilebilirlik 
konusunda sıkıntı yaşadıkları, bölgede yaşayan ailelerin çoğunun imkan dahilinde Gölcük içinde başka bir konutta yaşamak istedikleri verilerine ulaşılmıştır. Bu durum deprem sonrası yapılan yer seçim kararlarında planlama aşamasının tam anlamıyla çözümlenemediğinin göstergelerinden biridir.

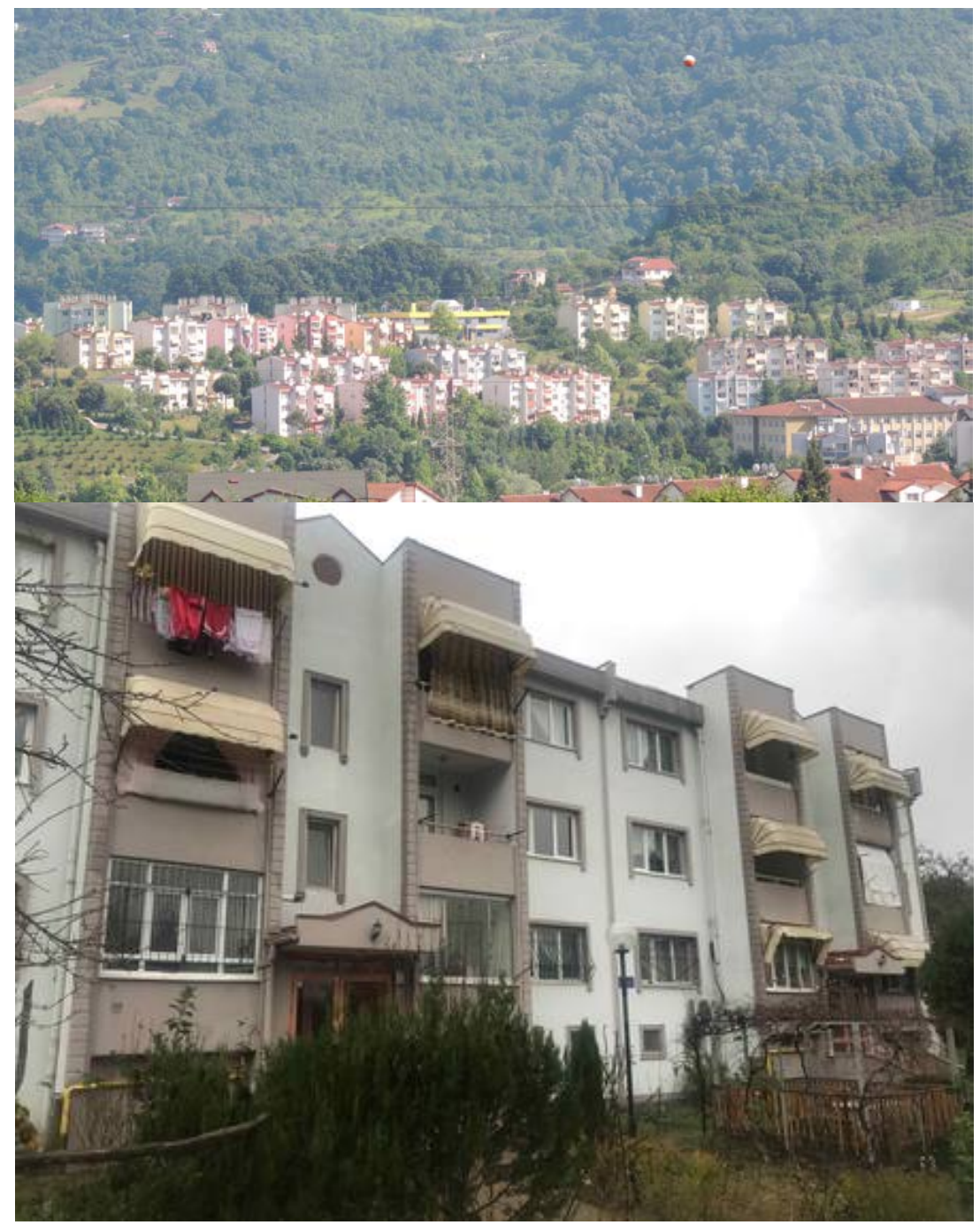

Şekil 4. Şirinköy Kalıcı Konutlarından bir görünüm (Uzuner Arşivi, 2019)

Kalıcı konutların inşa edilmesiyle özel inşaat firmaları ilçenin güney çeperlerinde konut üretimini hızlandırmıştır. Deprem öncesi kentin kıyı ve merkez kesimlerinde yoğun olan yapılaşma, deprem sonrasında bu bölgenin daha fazla hasar almasıyla genellikle onarımgüçlendirme geçirmiş ve fiziksel eskimeye uğramış konut stoğunun yoğun olarak bulunduğu yerleşimler olmuştur. Yeni yapılan konutların ise kentin güney çeperlerinde artmasıyla birlikte konut yerleşimleri kuzeyden güney kesimlere doğru bir yayılma göstermiştir. Buna ek olarak depremden sonra büyük hasarın yaşandığı mahallelerden biri olan Denizevler Mahallesi'nde Gölcük Belediyesi ve TOKI işbirliği ile yürütülen 'Gölcük Kentsel Dönüşüm Projesi' çalışmaları yapılmaktadır (Şekil 5 ve Şekil 6). Bu proje kapsamında kentin güneyinde bulunan ve zemin sağlamlığına bağlı olarak Sivritepe bölgesi rezerv alan olarak belirlenmiştir. İnşa süreci tamamlanan bu projede 541 konut, 14 dükkan ve 1 cami bulunmaktadır. Bu projenin yer seçimi kararlarında depreme dayanıklıı̆ı arttırmak için zemini sağlam arazinin tercih edilmesiyle kalıcı konutların planlama aşamasında izlenen yöntemle benzer bir karar alındığı görülmektedir. Proje, ilk bakışta depreme dayanıklılık ve zemin sağlamlığı konusunda doğru bir tercih olarak bilinse de; bu kararın erişilebilirlik, 
mekânsal kurgu, kullanıcı sosyal yaşamı ve yere olan aidiyet gibi planlama girdilerinden daha ön planda tutulduğu görülmektedir. Ayrıca yerleşime kapalı ve ormanlık arazi olan bu alanlar aynı şekilde imara açılarak, gelecek uzun vadede doğal kaynakların tahrip edilmesine kadar sürdürülebilirliği tehdit eden nedenlerle sonuçlanabilir (Şekil 7).

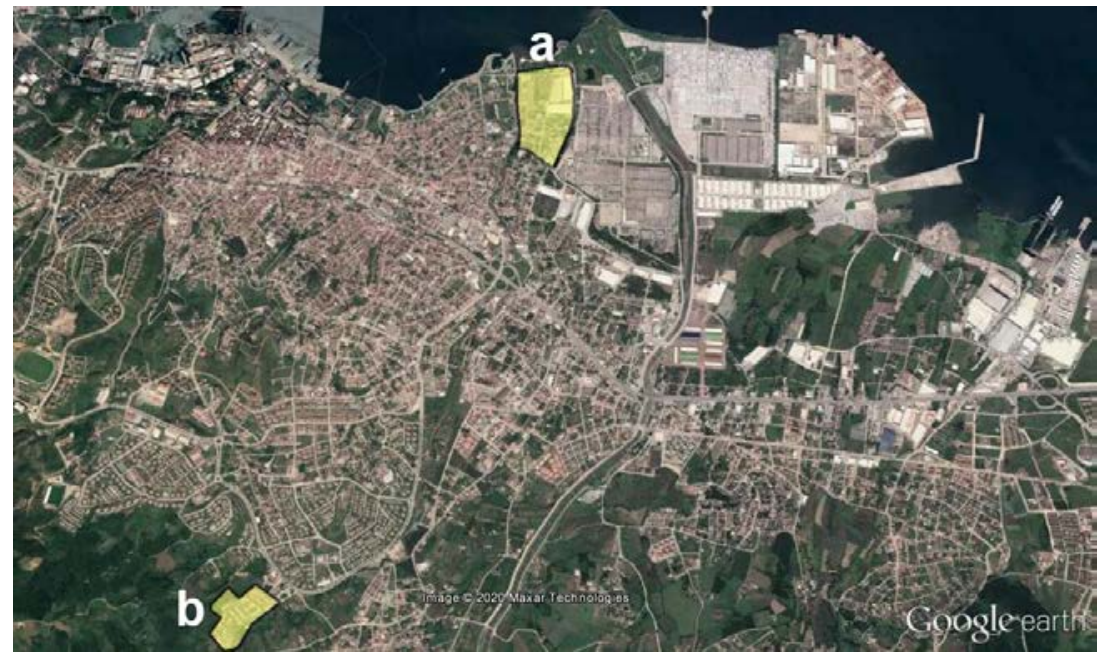

Şekil 5. Gölcük Kentsel Dönüşüm Projesi kapsamında konut yapılarına ait dönüşüm ve rezerv alanları

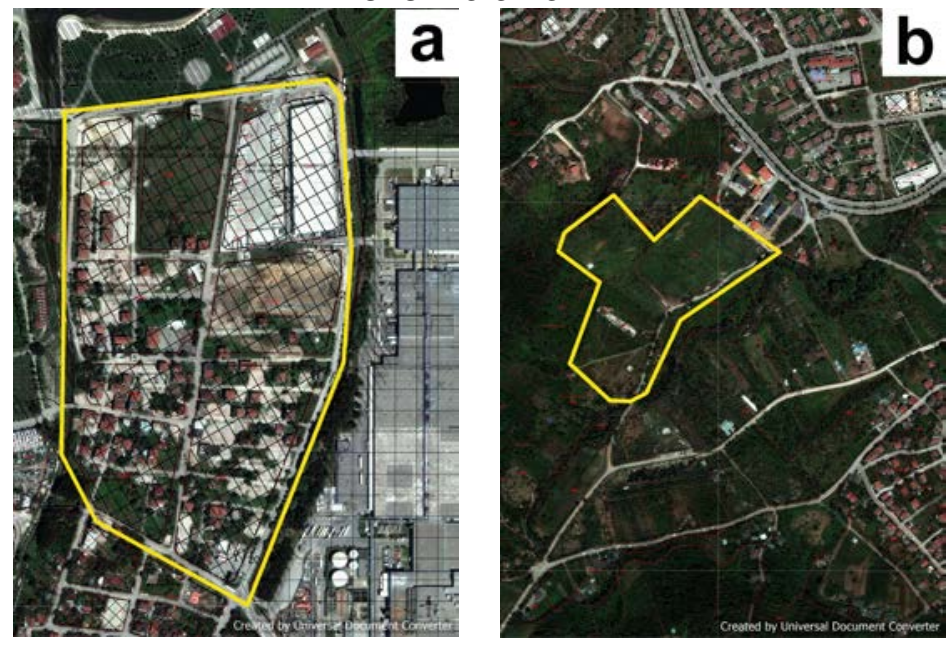

Şekil 6. Gölcük Kentsel Dönüşüm Projesi kapsamında Denizevler Mahallesi dönüşüm alanı (a) ve projenin uygulandığı Sivritepe Rezerv Alanı (b) yakın görüntüleri

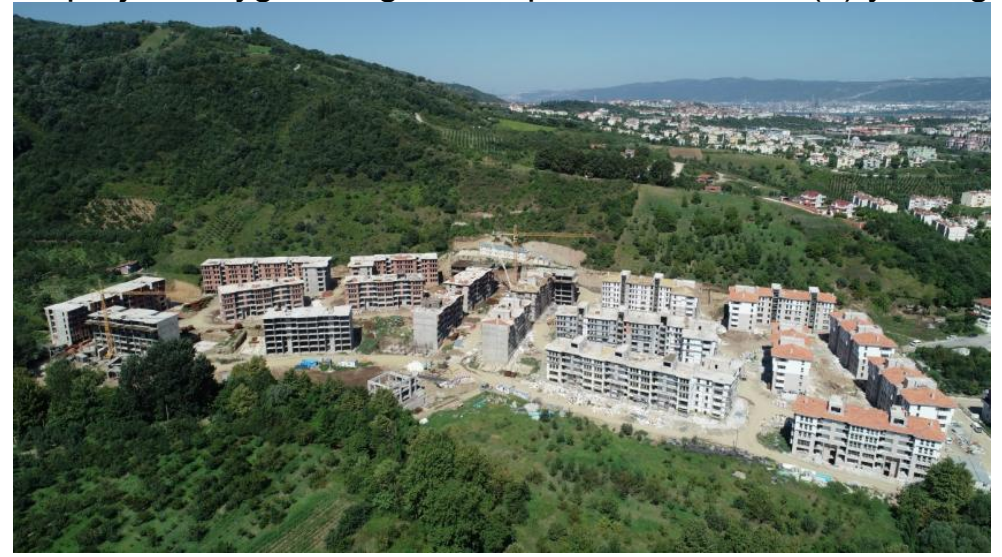

Şekil 7. Gölcük Kentsel Dönüşüm Projesi kapsamında Sivritepe bölgesindeki konutlardan görünüm (URL-2) 
Kentte konut gelişimi ve kullanıcı tercihlerine bağlı olarak kent dokusu üzerinde ciddi anlamda sosyo-ekonomik eşitsizlikten doğan konut çeşitliliği göze çarpmaktadır. Merkezden uzak, yeşil alanlara yakın olan güney çeperlerdeki konutlar bölge içindeki kullanıcılar için daha çekici hale gelmiştir (Şekil 8). Bu bölgelerde daha çok orta ve yüksek gelir grubuna yönelik az katlı, müstakil veya tek ev ölçeğindeki konutların sayısı günümüze değin artmıştır. Zeminin sağlam olmadığı, daha yoğun yapılaşma, onarım-güçlendirme geçirmiş ve zamanla fiziksel eskimeye uğrayan konutların yer aldığı kıyı ve merkez kesimler ise daha az talep görmesinden dolayı, genellikle alt ve orta gelir grubuna yönelik konut sahipleri yaşamaya devam etmektedir (Şekil 9). Aynı zamanda bu alanların kullanıcılar tarafından fiziksel ve sosyo-ekonomik faktörlerini tercih etme imkanlarının daha kısıtlı olduğu görülmektedir.
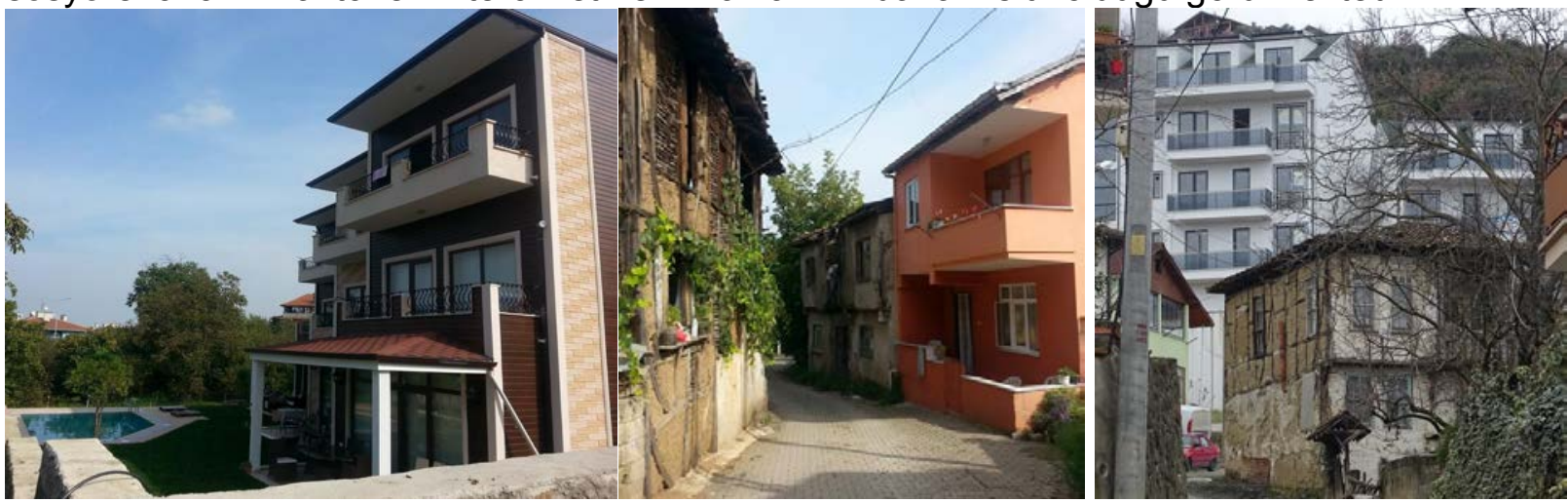

Şekil 8. Kentin güney çeperlerinde kırsal doku çevresindeki konutlar
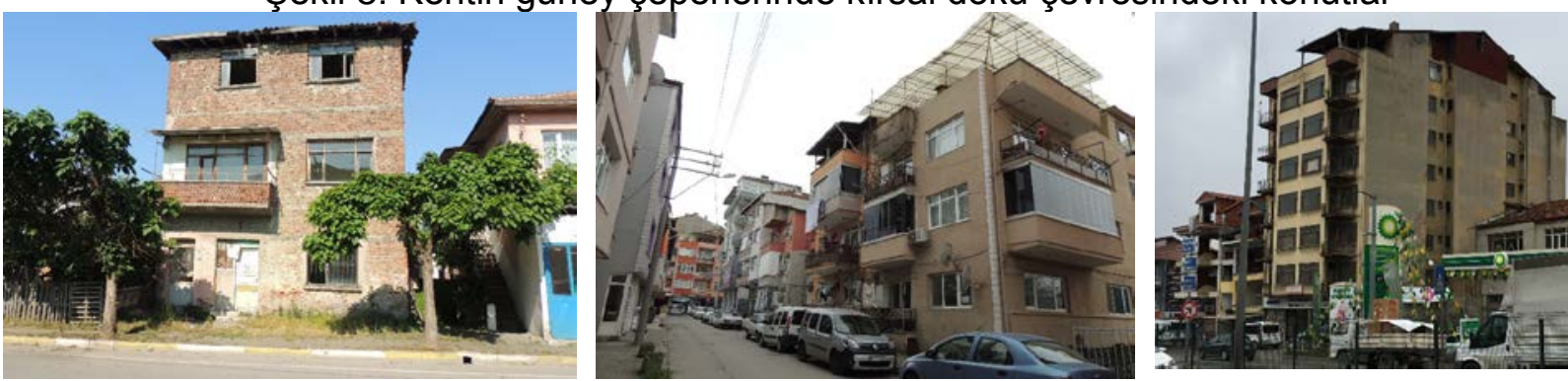

Şekil 9. Kentin kıyı ve merkez kesimlerinde bulunan konut dokuları

Yukarıda bahsedilen tüm bu yapılaşma kararları, güney çeperlerdeki tarım alanları ve doğal kaynakların bulunduğu arazilerin imara açılmasına neden olmuş, kentin ekolojik dirençliliği ve sürdürülebilirliği konusunda tehdit oluşturmaktadır. Bunun yanında tarihsel süreçte güney çeperlerde gelişen, tarihi ve mimari örneklerin bulunduğu kırsal dokunun korunması konusunda ciddi sonuçlar doğurmaktadır.

\section{SONUÇLAR}

Doğa olaylarının afete dönüşmesi, insan kaynaklı gerçekleşen etkinliklerin olumsuz bir sonucu olarak karşımıza çıkmaktadır. Deprem kuşağında olan Türkiye, tarih boyunca birçok deprem geçirmiş olmasına rağmen günümüzde deprem güvenlikli konut üretimi ve planlamada halen yeterli önlemlerin alınmadığı görülmektedir. Bunun en büyük örneğini 17 Ağustos 1999 yılında gerçekleşen Marmara Depremi göstermiştir. Depremin sonucunda ülke genelinde önemli bir farkındalık oluşturulmaya başlanmıştır. Depremin sonucunda yapılar üzerinde oluşan hasar nedenlerinin en başında yanlış yer seçimi gelmektedir. Deprem etkisiyle yeniden dönüşen ve planlanan konut alanlarının mekânsal yerleşim düzenleri ve kent dokusu üzerindeki konumları, kentin sahip olduğu dirençliliği ve sürdürülebilirliği ile doğrudan etkilidir. Konuyu Kocaeli/ Gölcük özelinde ele almak, problemin yarattığı etkiyi ve nedenlerini analiz etmek açısından daha yerinde olmuştur. Çalışmada, kentin belirli 
kesimlerinde deprem sonrası konut gelişimi ve kentsel yayılma alanlarının dirençlilik ve sürdürülebilirlik kavramları açısından kente etkisi değerlendirilmiştir.

Gölcük'te deprem öncesi konut gelişimi sanayi ve askeri alanların konumu, erişilebilirlik, ekonomik kaynakların konumu ve manzara gibi nedenlerden dolayı kentin kıyı ve merkez kesimlerinde yoğunlaşmıştır. Gün geçtikçe bu noktalarda nüfus miktarına bağlı olarak artan yapılaşma, dağlık alanlarında da tarihsel kalıntıların bulunduğu kırsal dokusuyla birlikte şekillendiği bir kent dokusu halini almıştır. Deprem anında yıkıcı etkinin fazla olmasıyla mevcut yerleşimlerde bulunan yapı stoğu ciddi anlamda bozulmuştur. Daha çok zemin özelliklerinin ön planda olması, ormanlık ve doğal kaynakların yer aldığı kentin güney kesimlerinde yerleşimlerin artmasına neden olmuştur. Bu durum kent dokusunun kırsal alana doğru yayılmasına, çeperlerdeki konut dokusunun kent ve kır arasında kalmış başka bir tipolojiye evrilmesine ve kırsal dokunun sahip olduğu özgün değerlerin mevcut kent dokusunun izlerine dönüşmesine sebep olmuştur.

Kentin kıyı ve merkez kesimlerinde genellikle onarım-güçlendirme geçirmiş ve fiziksel eskimeye uğramış konutların yoğun olarak bulunması, kentin güneyinde ise deprem sonrası kalıcı konutlar, kentsel dönüşüm kapsamında yapılan konutlar, az katlı, tek ev veya site ölçeğindeki yapıların sayısının artması; fiziksel çevrenin ayrışmaya başlamasına, yapılaşma alanlarının genişlemesine neden olmuştur. Bu ayrışmanın önemli sebeplerinden biri, konutların ekonomik değerindeki değişime bağlı olarak kullanıcıların gelir durumunun da değişkenlik göstermesidir. İmara açılan dağlık ve ormanlık alanlarda yaşanan bu tahribat; yeşil alanların yok olması ve düzensiz yapılaşma gibi fiziksel, bölgede yaşayan insanların birbirleriyle ve çevre ile olan ilişkilerinde yaşanan sorunlar sosyal, konutların ekonomik değerindeki düzensizlik ve kullanıcıların gelir durumuna bağlı olarak yaşadıkları sınırlılıklar ise ekonomik çevre üzerinde tehdit oluşturmaktadır. Tüm bunlar kullanıcı bilinci ve yapı üretimi arasındaki döngünün ne kadarını öğrenip, uygulayabildiğimizin göstergesidir.

Yerel yönetimler, üniversiteler, sivil toplum kuruluşları ve bu planlama sürecine dahil olan birçok aktörün bilimsel verilere dayalı gerekli önlemlerin doğru bir şekilde alınması gerekmektedir. Bu kurum ve kuruluşların deprem sonrası planlama konusunda ilgili yasa ve yönetmeliklerin yeniden gözden geçirilmesi için çalışmaların yapılması, kullanıcıların ise depreme dayanıklı kaliteli konut edinme ve planlama ile ilgili farkındalığının oluşturulmasına yönelik bütüncül yaklaşımla gerçekleşecek çözüm önerilerine intiyaç vardır.

\section{KAYNAKLAR}

Akıncıtürk, N. (2003). Ülkemizdeki deprem etkileri ve yapısal tasarımda alınması gereken önlemler, Uludağ Üniversitesi Mühendislik Mimarlık Fakültesi Yayını, Bursa.

Coşkun, Z.K. (2005). Deprem sonrası planlamada yeni yerleşim bölgesi yaklaşımı: Adapazarı örneği. Yüksek Lisans Tezi, Gazi Üniversitesi Fen Bilimleri Enstitüsü, Ankara.

Durmaz, A. (2008). Gölcük'te 17 Ağustos 1999 Depremi sonrasında kurulan yeni yerleşim alanlarının şehrin gelişimine etkileri. (Yayınlanmamış Yüksek Lisans Tezi), Sakarya Üniversitesi Sosyal Bilimler Enstitüsü, Sakarya.

Gerçek, D. ve Güven, T. (2016). Kentsel Dirençliliğin Coğrafi Bilgi Sistemleri ile Analizi: Deprem ve Izmit Kenti. Harita Teknolojileri Elektronik Dergisi, Cilt: 8, No: 1.

İncir, A. (2013). 17 Ağustos Etkinlikleri ve Yapılan Anket Çalışmalarının Değerlendirilmesi. TMMOB 2. İzmir Kent Sempozyumu, İzmir, (s. 169-178) içinde.

Kaya, S. (2001). Marmara Depremi Sonrası Konut Üretimi Organizasyonu ve Kocaeli- 
Bahçecik Örneği. Yüksek Lisans Tezi, YTÜ Fen Bilimleri Enstitüsü, İstanbul.

Köksal, G. (2013). Gölcük Mimari Miras, Gölcük Vizyon 2023, Kocaeli: Kültür Vizyon Serisi 3.

Köroğlu, J. N. (2007). 17 Ağustos 1999 Marmara Depremi'nin Gölcük ve Civarındaki Çevresel Etkileri. Yüksek Lisans Tezi, İstanbul Üniversitesi Sosyal Bilimler Enstitüsü, İstanbul.

Orhan, E. (2016). Building the community resilience: Lessons from business preparedness in the case of Adapazarı, Turkey, 40(1) (s. 45-64) içinde.

Südaş, İ. (2004). 17 Ağustos 1999 Marmara Depreminin Nüfus ve Yerleşme Üzerindeki Etkileri: Gölcük (Kocaeli) Örneği. Ege Coğrafya Dergisi, Cilt: 13, (s. 73-91) içinde.

Türkoğlu, H. (2014). Afete Dirençli Şehir Planlama ve Yapılaşma, İSMEP, İstanbul, 8-9.

Türkoğlu, N. (2001). Türkiye'nin Yüzölçümü ve Nüfusunun Deprem Bölgelerine Dağılışı. TÜCAUM Dergisi, Sayı:8, (s. 133-148) içinde.

Yücel, G. ve Arun, G. (2010). Mevcut Yerleşimlerin Deprem liçin Fiziksel ve Sosyal Etkilenebilirliğinin Belirlenmesi: Avcılar Örneği. Megaron Dergisi, Cilt: 5, No:1, (s. 23-32) içinde.

URL-1: http://www.golcuk.gov.tr'den 14.06.2019 da alınmıştır.

URL-2: http://www.yenigolcuk.com/mobil.php?islem=haber\&id=29981\&i=1'den 20.12.2019 da alınmıştır. 